\title{
Unravelling the complex geological evolution of one of Earth's final remaining frontiers: East Siberia
}

James S.K. Barnet ${ }^{1}$ and Benedikt M. Steiner ${ }^{2}$

1. School of Earth and Environmental Sciences, University of St Andrews, Irvine Building, North Street, St Andrews KY16 9AL, United Kingdom; jsb24@standrews.ac.uk

2. Camborne School of Mines, University of Exeter, Penryn TR10 9FE, United Kingdom; B.Steiner@exeter.ac.uk

\begin{abstract}
East Siberia represents one of the most remote and inhospitable regions on the planet, home to the coldest permanently inhabited settlement on Earth (Oymyakon), where temperatures frequently fall below $-50^{\circ} \mathrm{C}$ in winter. Geological investigations in this part of northern Asia are severely hampered by thick permafrost, a lack of infrastructure, vast tracts of barren uninhabited rough terrain, and political challenges. However, the rocks buried below the freezing tundra and taiga of this remote land provide evidence of an interesting and diverse geological history, including vast hypersaline salt basins, voluminous volcanic eruptions, Himalayan-style mountain ranges, and extensive swamps. Following a comprehensive study of publically available literature, the majority published in Russian language and challenging to obtain in the UK, we aim to decipher the diverse and complicated geological history of this remote region over the past 1650 million years.
\end{abstract}

\section{Geological setting of East Siberia}

East Siberia is underlain by the Siberian Craton, comprising a series of ancient continental crustal blocks of Archean-Paleoproterozoic age, which had amalgamated by the late Paleoproterozoic ( 1800 Ma). The Siberian Platform overlies a significant portion of the Siberian Craton, where a thick suite of Mesoproterozoic to Mesozoic siliciclastic (sandstones and shales) and carbonate (limestone and dolomite) rocks were deposited. The Siberian Platform is framed by mountain ranges comprising intensely deformed rocks, formed by a long and protracted history of continental accretion onto the margins of the Siberian Craton. These include the Baikal-Patom fold belt to the south, the Verkhoyansk fold belt to the east, and the Taimyr fold belt to the north (Figure 1). The western margin of the Siberian Craton is now largely buried beneath the Mesozoic West Siberian Basin.

\section{Rifting, carbonate platforms and hypersaline salt basins of the Proterozoic and Early Paleozoic}

Rifting of the Siberian Craton took place during the Riphean (Mesoproterozoic-early Neoproterozoic; 1650-650 Ma), with thick syn-rift organic-rich shales deposited within a network of restricted marine basins. Riphean black shales, rich in primitive 
algae and bacteria, are believed to form source rocks for some of the oldest oil in the world across the south-western Siberian Platform. These syn-rift sediments are unconformably overlain by regional deposition of Vendian (late Neoproterozoic) and Cambrian post-rift rocks. Initially, predominantly siliciclastic sediments were deposited during the late Neoproterozoic $(\sim 60 \mathrm{Ma})$, sourced from mountains framing the southern margin of Siberia. However, denudation of these mountains and a reduction in siliciclastic input resulted in the widespread development of a shallow marine carbonate platform across a large part of the Siberian Platform by the end of the Neoproterozoic and Early Cambrian ( $541 \mathrm{Ma})$. During the Cambrian Period and throughout the Early-Middle Paleozoic, Siberia was located at a low latitude with a hot and tropical climate. The shallow marine carbonate platform was characterised by some topography and during periods of sea level fall, large restricted hypersaline basins developed within the depressions, where extensive evaporation of seawater took place under the hot climate and thick halite (salt) deposits up to several hundred metres thick accumulated.

\section{Middle Paleozoic rifting}

Rifting of a triple junction took place along the eastern part of the Siberian Platform during the Late Devonian ( 380 Ma), above a supposed mantle plume (Figure 2a). Triple junctions are characterised by a "successful" rift arm, which often results in continental break up and formation of an oceanic basin, and a "failed" rift arm, which is characterised by extension and thinning of continental crust without progressing to the stage of continental breakup. Mesozoic rifting of the North Atlantic provides a geological analogue of a triple junction in Western Europe, with the North Atlantic representing the "successful" rift and forming an oceanic basin, while the North Sea represents the "failed" rift arm and is floored by thinned continental crust.

In East Siberia, the successful arm of the triple junction stretched from just east of the Lena Delta area towards the north-western coast of the Sea of Okhotsk, ultimately resulting in continental breakup and formation of the Oymyakon Ocean during the Late Devonian-Jurassic. Rifting of the Oymyakon Ocean is believed to have severed the Omulevka and Omolon microcontinents away from the Siberian Craton, with subsequent drift of these smaller continental blocks away from Siberia along the opposite margin of the Oymyakon Ocean during the Late Paleozoic. The "failed" rift arm formed the Vilyuy rift, a roughly NE-SW trending rift basin which determined the palaeogeography of eastern Siberia throughout the remainder of the Late Paleozoic and Early Mesozoic. Formation of the continental Vilyuy rift was accompanied by voluminous volcanism during the Late Devonian, followed by the deposition of syn-rift organic-rich marine clays and limestones within the isolated and restricted Ygyatta and Kempendiay depressions, separated by the uplifted Suntar horst block (Figure 3). Subsidence rates within the Vilyuy and associated rift basins in East Siberia significantly decreased at the end of the Devonian, and a thick succession of post-rift siliciclastic sediments were deposited along the broad passive margin of the Oymyakon Ocean during Carboniferous-Jurassic time. Carboniferous-Early Permian sediments were predominantly of marine origin, however by the Late Permian ( 255 
Ma), a vast low-lying swamp developed across a large part of the Siberian Platform. A warm and humid climate allowed extensive vegetation to flourish, forming thick peat deposits within the extensive Tunguska Basin in the centre of the platform, as well as the Vilyuy Depression along its eastern periphery (Figure 4).

\section{Late Paleozoic accretion of the Kara microcontinent onto northern Siberia}

Accretion of the Kara microcontinent, encompassing the Severnaya Zemlya archipelago and northern Taimyr Peninsula, to the northern passive margin of Siberia took place during the Late Carboniferous-Early Permian ( $300 \mathrm{Ma})$. This collision led to intense crustal deformation and melting, forming a belt of intensely deformed rocks known as the Taimyr fold belt and intrusion of large granite plutons, which have been used to date the age of continental collision. A foredeep, now partly occupied by Lake Taimyr, formed in front (to the south) of the Taimyr fold belt. Collision of Kara with Siberia represented the final closure of the Uralian Ocean, ultimately forming one extensive chain of deformed rocks extending from the Ural mountains on mainland Russia, through Novaya Zemlya to Severnaya Zemlya and northern Taimyr (Figure 1).

\section{Siberian Traps and the Permian-Triassic mass extinction}

The Permian-Triassic boundary was associated with the greatest extinction event of the past 540 million years, when up to $96 \%$ of marine species on Earth became extinct. A major contributor to this event was eruption of the Siberian Traps flood basalts, which covered a significant portion of the Siberian Craton (Figure 5). The main pulse of Siberian Traps volcanism took place over a geologically short period of time, spanning around 1 million years across the Permian-Triassic boundary ( 252 Ma), although episodic smaller eruptive events continued until the Middle-Late Triassic. Eruptions were focused in the Tunguska Basin where $>1 \mathrm{~km}$ of basalt was extruded, now forming a broad elevated remote basaltic plateau dissected by a complex network of intricate river systems (known as the Central Siberian Plateau). These immense volumes of basalt were erupted through thick Permian peat deposits, metamorphosing vast amounts of organic matter and releasing significant quantities of thermogenic methane, amplifying global warming during this time and contributing to the severity of the extinction.

\section{Early Mesozoic continental collision in southern Siberia}

The southern margin of Siberia remained active almost continuously throughout the Devonian-Jurassic. Opening of the Mongol-Okhotsk Ocean (a gulf of the palaeoPacific) took place during the Early Permian, separating the Siberian Craton from central and southern Mongolia. Active subduction of ocean crust along both margins created the Selenge volcanic belt along the southern margin of Siberia, and the Middle Gobi volcanic belt along the northern margin of Mongolia. Following collision of the North China Block with Mongolia at the Early/Late Permian boundary, subduction of Mongol-Okhotsk crust only took place beneath the southern margin of Siberia. 
Formation of the Triassic-Jurassic Great Khingan volcanic belt took place through Transbaikal, and the largely Jurassic age Stanovoy volcanic belt along the Stanovoy Block of the south-eastern Siberian Craton, only fragments of which have been preserved. Behind the Stanovoy volcanic belt, the South Yakutian back-arc basin formed, where a thick series of continental economic coal-bearing sediments were deposited during Jurassic-Early Cretaceous time, along with volcanic and volcaniclastic rocks sourced from the Stanovoy volcanic belt to the south. The Great Khingan-Stanovoy volcanic belt continued eastward into the Uda-Murgal island arc, behind which was a marine back-arc basin supposedly floored by ocean crust, separating the Uda-Murgal arc from the Omulevka and Omolon microcontinents, which rifted away from the Siberian Craton during the Devonian.

The Mongol-Okhotsk Ocean progressively closed from west to east, with an abrupt transition from marine clastics to continental molasse at the Early/Middle Jurassic boundary in Transbaikal, suggesting closure of the ocean in this area (Figure 2b). Marine sediments continued to accumulate along the eastern portion of the suture zone in the Uda and Torom basins until the Late Jurassic. Closure of the MongolOkhotsk Ocean and the resulting collision of the Mongolia-North China Block with Siberia formed the Khangay, Khentey and Dauria mountain ranges, which became important sediment provenances to sedimentary basins across Mongolia and southwest Siberia. Uplift of the Great Khingan and Stanovoy mountains formed an important sediment provenance for the South Yakutian Basin and south-eastern Siberian Platform.

\section{Termination of the passive margin and Late Mesozoic continental collision in eastern Siberia}

A mixture of continental and marine shales and sandstones were deposited along the northern and eastern passive margins of Siberia until the Middle-Late Jurassic. A fairly continuous sequence of marine shales and organic-rich limestones were deposited during Early Triassic marine transgression, in contrast to the predominantly continental rocks with poorly constrained age control deposited across much of Europe in the heart of the Pangaea supercontinent during this time. Some of the best and most complete outcrops of these Early Triassic marine rocks are found along and in the vicinity of the lower reaches of the Olenek River (Figure 5), which is how the name of the youngest and largest stage of the Early Triassic (Olenekian) was derived. Maximum transgression occurred during the early Toarcian ( 183 Ma), when black organic-rich shales of the Suntar and Kiterbyutsk formations were deposited across large portions of the eastern and northern margins of the Siberian Platform (Figure 6). Black shales were also deposited in the West Siberian Basin (Togur Formation) as well as elsewhere in the Arctic realm during this time, during an oceanic anoxic event of global significance. Under a globally warm and humid climate, extensive peatforming swamps developed in continental basins across the south-western Siberian Platform to the north of Irkutsk, with the peat subsequently buried and heated to form economic coal deposits. Subsidence of the east-west trending Yenisey-Khatanga Basin along the northern margin of Siberia took place during the Early Jurassic, where 
a great thickness of Jurassic and Early Cretaceous siliciclastic sediments were deposited.

A complex series of tectonic events commenced from the Middle Jurassic, which would ultimately result in closure of the Oymyakon Ocean and the accretion of a number of continental terranes onto the eastern margin of the Siberian Craton. Firstly, closure of a back-arc basin resulted in accretion of the Omulevka Terrane with the Alazeya island arc complex, forming the Kolyma-Omolon Superterrane and initiating a compressional tectonic regime along the adjacent (eastern, in present co-ordinates) margin of the Oymyakon Ocean. This compressional regime instigated the subduction of Oymyakon Basin ocean crust beneath the Kolyma-Omolon Superterrane and resulted in generation of the Uyandina-Yasatchnaya arc along the leading edge of the terrane (Figure 2c). The eastern margin of Siberia remained passive throughout this time, however the Late Jurassic was characterised by a significant marine regression and increasingly continental sandy facies cap the post-rift sedimentary sequence of eastern Siberia. Closure of the Oymyakon Ocean and collision of the Kolyma-Omolon Superterrane with the eastern passive margin of the Siberian Craton took place during the late Tithonian-Early Cretaceous ( 150-138 Ma). Analogous with the collision between India and Eurasia forming the Himalayas, the collision of Siberia with the Kolyma-Omolon Superterrane created intense crustal deformation and uplift of the Verkhoyansk mountain range along the suture zone, which may have reached Himalayan proportions during the Early Cretaceous. The Verkhoyansk mountain range represents a major topographic feature in East Siberia, a remote and inhospitable mountain range, its peculiar S-shape defined by the outline of the former passive eastern margin of the Siberian Craton.

Ongoing compressional forces resulted in westward propagation of the Verhoyansk fold belt and associated mountain range during the Early Cretaceous (Figure 7). In front (to the west) of the immense mountain range, rapid subsidence formed the westward-propagating Cis-Verkhoyansk Foredeep, which was filled with $>1 \mathrm{~km}$ of continental siliciclastic rocks eroded from the adjacent mountains and peat deposits. Westward propagation of the Verkhoyansk Orogeny and associated foredeep had largely ceased by the Middle Cretaceous, with a comparatively thin veneer of predominantly coarse clastics deposited across the basin during the Late Cretaceous.

\section{Formation of the Cretaceous "palaeo-Pacific Ring of Fire"}

Active subduction of palaeo-Pacific oceanic crust continued during the Cretaceous beneath the terranes accreted onto the eastern margin of Siberia, forming the extensive Okhotsk-Chukotka volcanic belt (Figure 2d). This extensive volcanic range, forming part of the "palaeo-Pacific Ring of Fire", stretched from the north-western coast of the Sea of Okhotsk to the Chukotka Peninsula. The volcanic highlands formed along the western part of this chain represented a sediment source for the southeastern part of the Siberian Platform during the Cretaceous and Cenozoic. Active subduction of Pacific oceanic crust shifted to the south-east during the Cenozoic following the accretion of a series of small continental terranes, and today forms the more familiar Japan-Kuril-Kamchatka-Aleutian chain of active island arcs. 


\section{Modern-day geography of East Siberia}

Aside from the Cenozoic (Oligocene) rifting of Lake Baikal, the deepest lake on Earth $(1,642$ metres deep), the modern-day structural framework of East Siberia had been established by the end of the Cretaceous. Vast long-lived river systems now flow through the sites of former Paleozoic and Mesozoic sedimentary basins, while the former southern, eastern and northern margins of the Siberian Craton are defined by belts of intensely deformed rocks and ancient mountain ranges (Figure 1). The Lena and Aldan rivers curve through the site of the former Early Cretaceous CisVerkhoyansk Foredeep in front of the S-shaped Verkhoyansk mountain range, and have probably existed in a broadly similar region since the Cretaceous Period. Indeed, the Lena River is sourced in the mountains of the Baikal-Patom fold belt and is the eleventh longest river on Earth at 4,294 kilometres in length. Similarly, the Vilyuy River, a major tributary to the Lena River, flows through the site of the former failed Late Devonian Vilyuy rift basin and is sourced from the vast elevated Siberian Traps plateau (Central Siberian Plateau), erupted into and uplifting the former Permian Tunguska Basin. The Khatanga River flows eastwards through the former Jurassic-Cretaceous Yenisey-Khatanga Basin into the Laptev Sea, bounded by the vast elevated Siberian Traps basalt plateau to the south, and remnant mountains of the Taimyr fold belt to the north. The extinct Cretaceous Okhotsk-Chukotka volcanic belt is represented by a mountain chain extending from the northern coast of the Sea of Okhotsk, northeastward through the Kolyma Range to the Chukotka Peninsula in the Russian Far East, with the active Pacific margin having long shifted to the south-east. East Siberia may be currently in a state of tectonic quiescence, but a casual glance at its topography is enough to suggest that this region has experienced more than its fair share of tectonic activity during an extremely active and complicated geological past. 


\section{Figures}

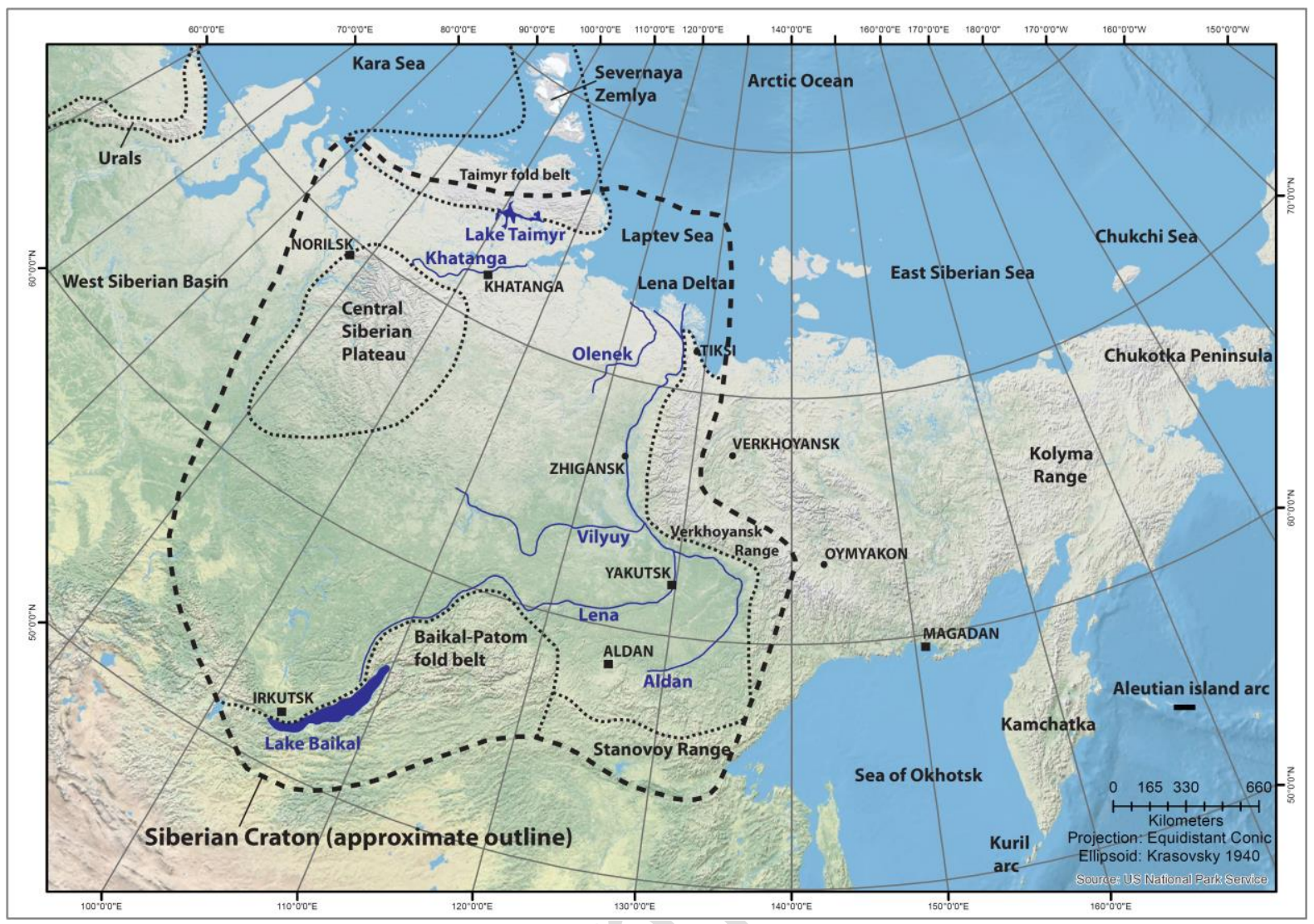

Figure 1. Topographic map of East Siberia and the Russian Far East, highlighting the key topographic and geomorphological features discussed in this article. 


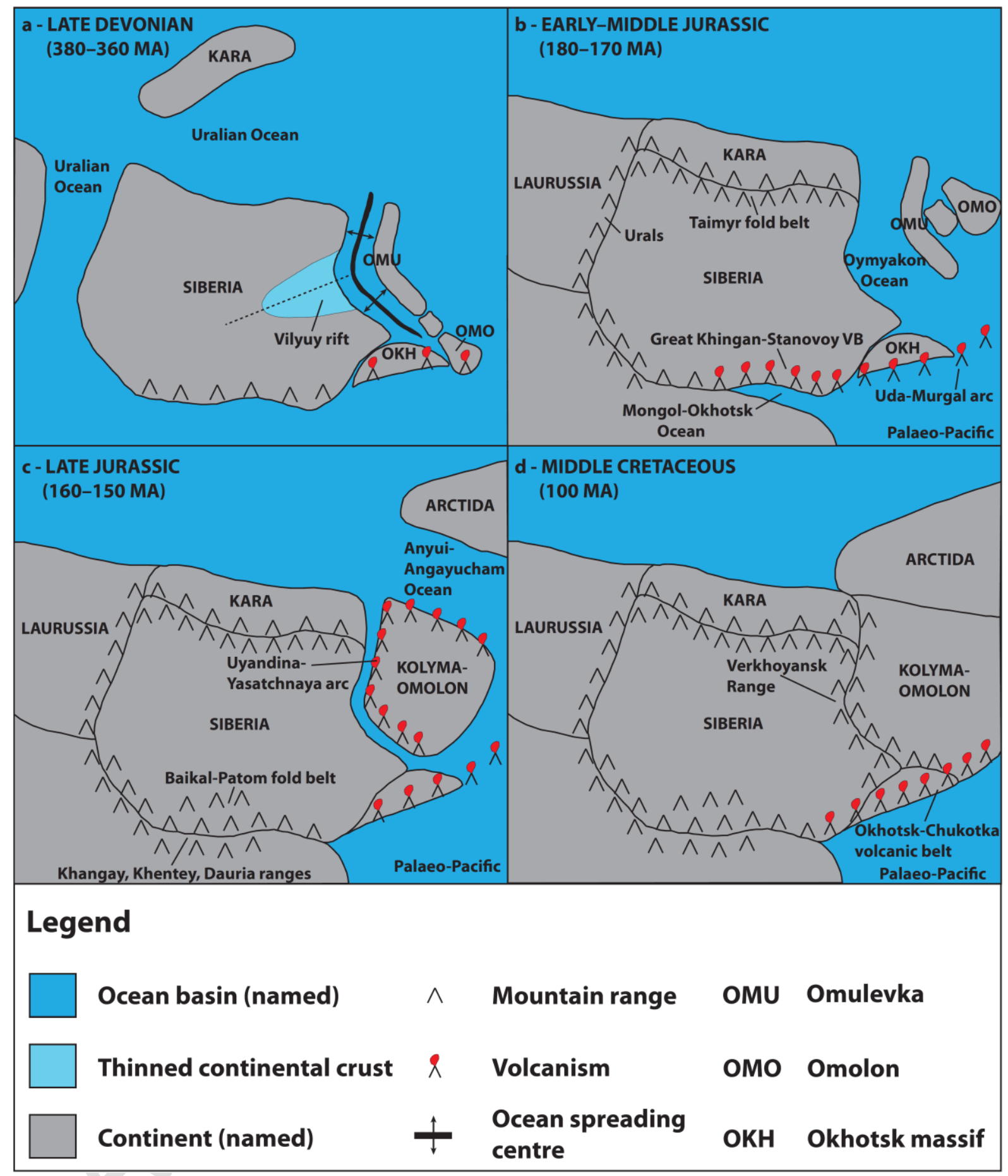

Figure 2. Cartoons depicting the tectonic evolution of the Siberian Craton during Late Devonian to Cretaceous times. 


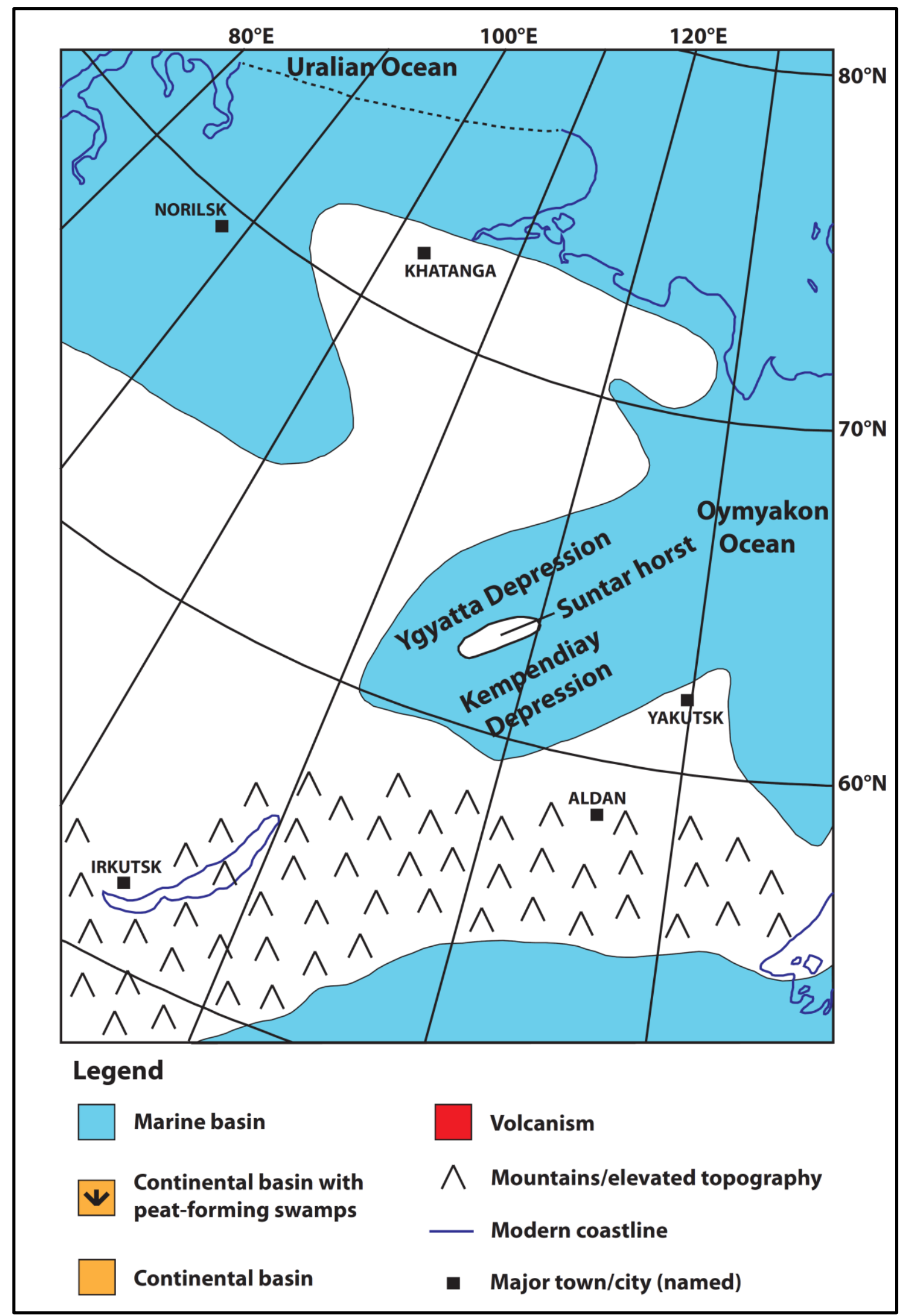

Figure 3. Palaeogeography of the Siberian Platform during the Late Devonian ( 380$360 \mathrm{Ma}$ ), illustrating Middle Paleozoic rifting. 


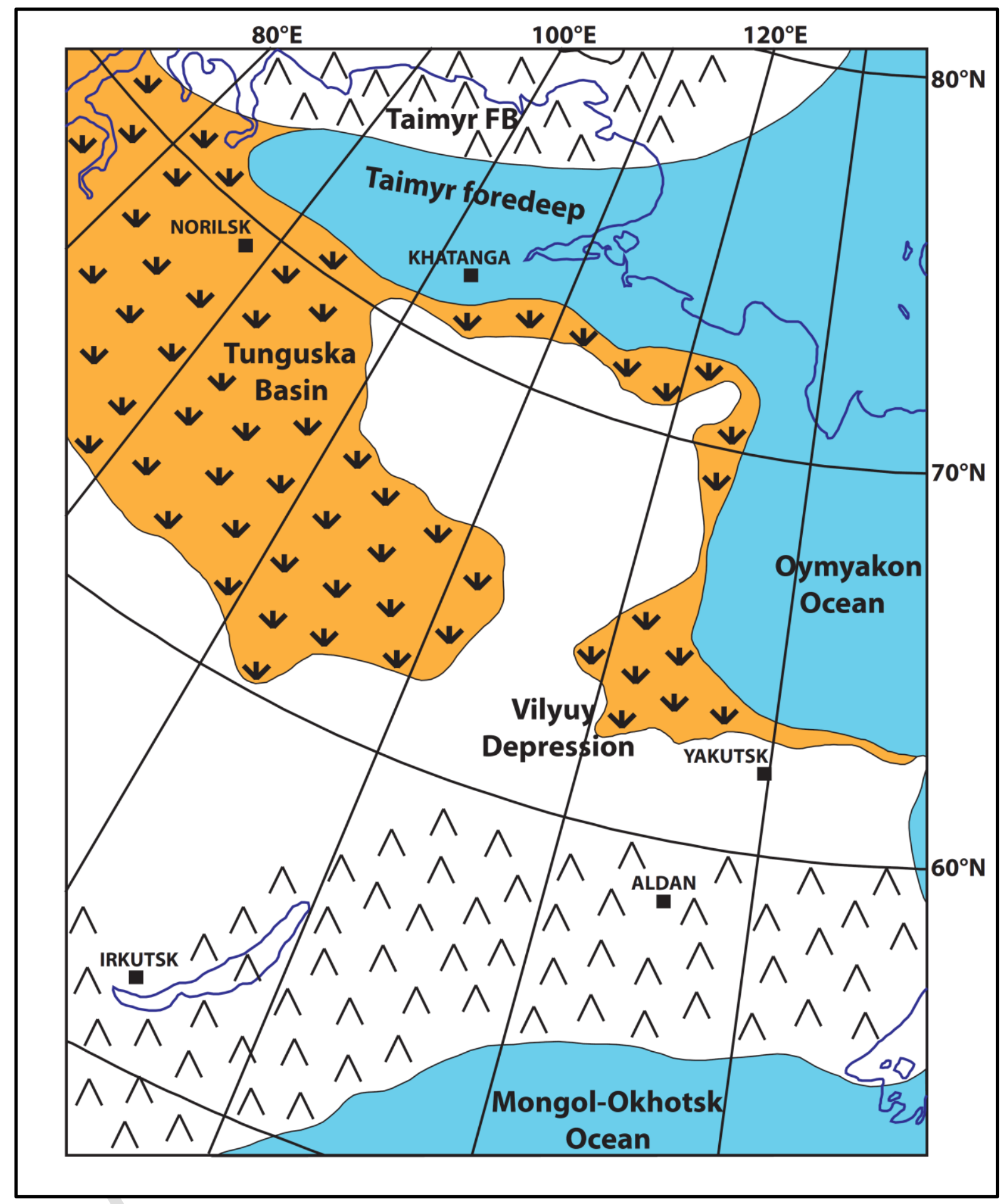

Figure 4. Palaeogeography of the Siberian Platform during the Late Permian ( 255 Ma), illustrating the distribution of peat-forming swamps. Legend is provided in Figure 3. 


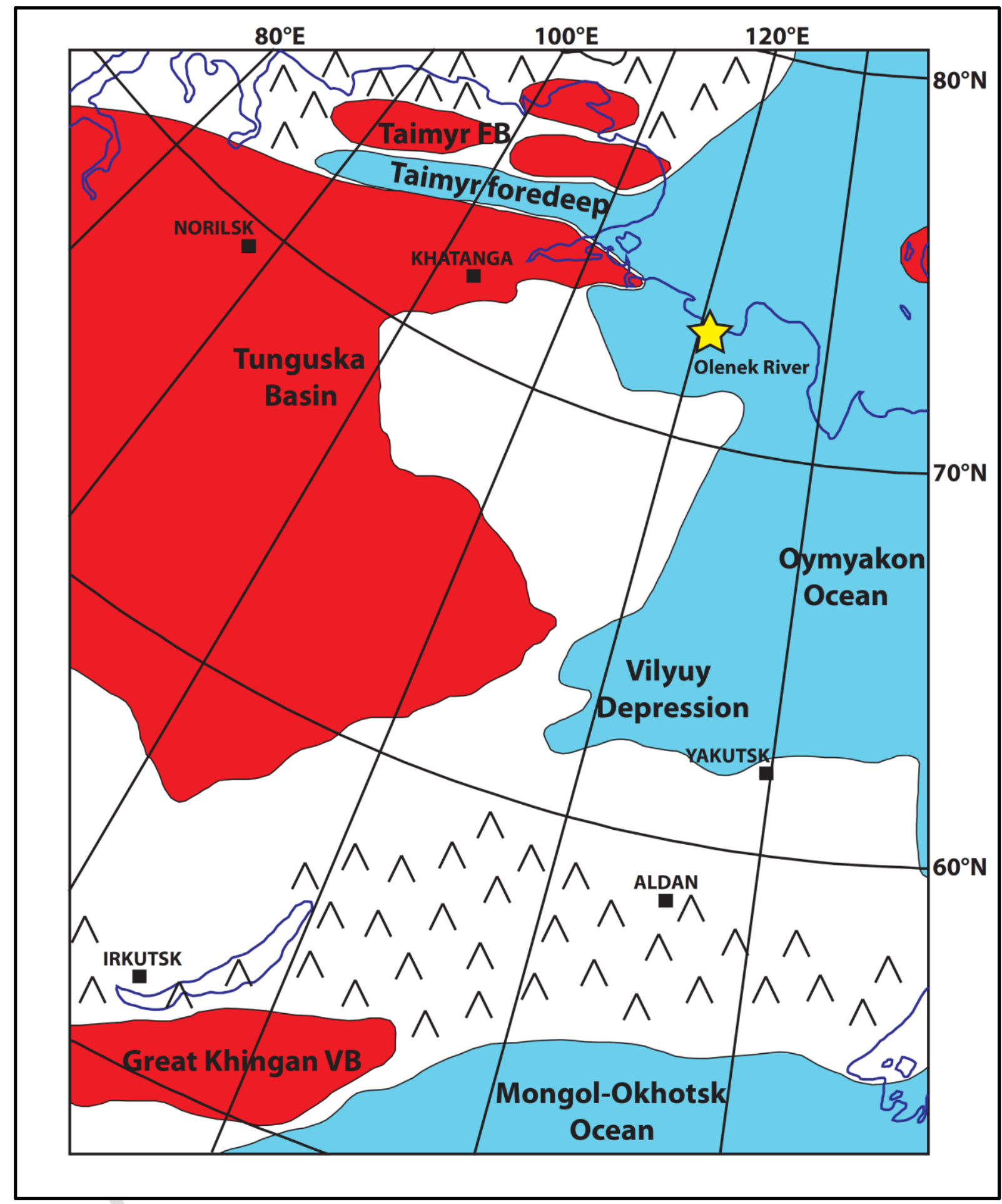

Figure 5. Palaeogeography of the Siberian Platform during the Early Triassic ( $250 \mathrm{Ma})$, illustrating distribution of the Siberian Traps and maximum marine transgression of the Olenekian stage. Legend is provided in Figure 3. 


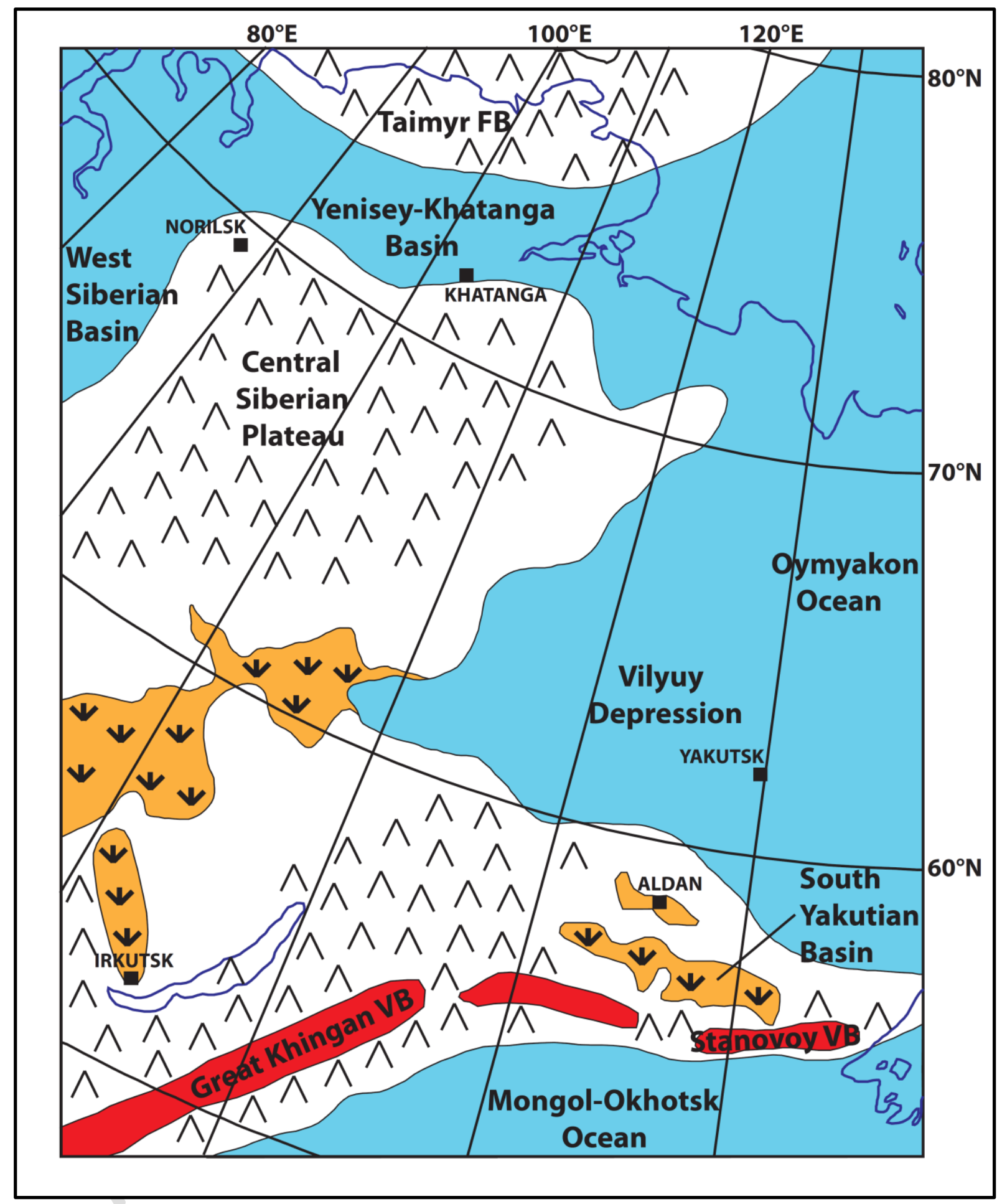

Figure 6. Palaeogeography of the Siberian Platform during the Early Jurassic ( $183 \mathrm{Ma})$, illustrating maximum marine transgression associated with the Toarcian oceanic anoxic event. Legend is provided in Figure 3. 


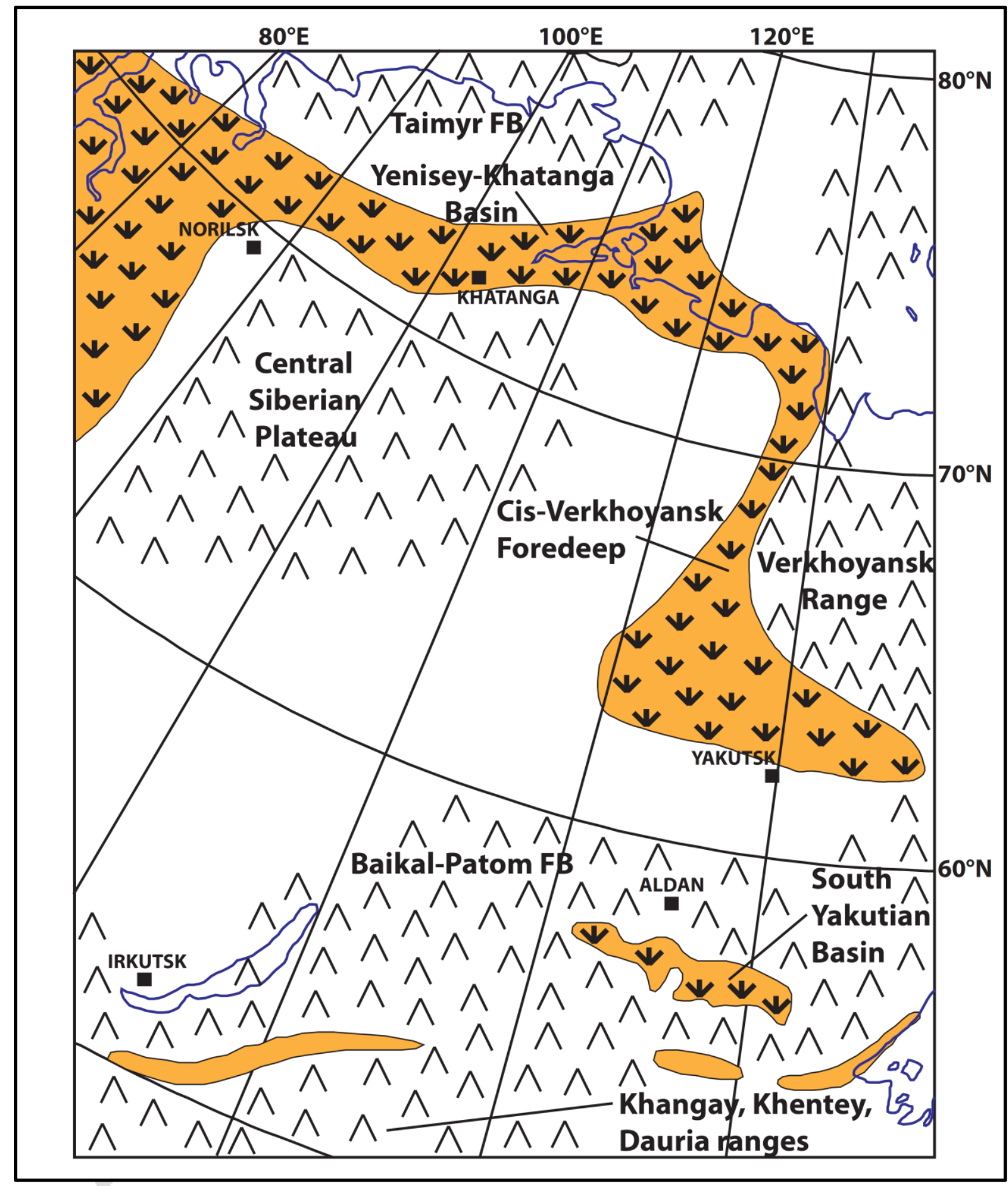

Figure 7. Palaeogeography of the Siberian Platform during the Early Cretaceous ( 140$130 \mathrm{Ma}$ ), illustrating the distribution of mountain belts and foredeep basins associated with continental collision. Legend is provided in Figure 3. 


\section{Suggested reading}

Cocks, L.R.M. \& Torsvik, T.H. 2007. Siberia, the wandering northern terrane, and its changing geography through the Palaeozoic. Earth-Science Reviews, v.82, pp.2974.

Khain, V.E. 1985. Geology of the USSR. E. Schweizerbartsche Verlagsbuchhandlung, Stuttgart, Berlin, 272p.

Nalivkin, D.V. 1973. The Geology of the U.S.S.R. University of Toronto Press, 855p.

Oxman, V.S. 2003. Tectonic evolution of the Mesozoic Verkhoyansk-Kolyma belt (NE Asia). Tectonophysics, v.365, pp.45-76.

Steiner, B.M. \& Barnet, J.S.K. 2017. Petroleum potential of the southern and eastern Siberian Platform, Russia: An evaluation of proven petroleum systems and directions for future exploration. XPLORE.GLOBAL, Exploration Targeting Series, v.2, 77p.

Zorin, Yu.A. 1999. Geodynamics of the western part of the Mongolia-Okhotsk collisional belt, Trans-Baikal region (Russia) and Mongolia. Tectonophysics, v.306, pp.33-56. 